\title{
Chlorophyll degradation by tetracycline and cadmium in spinach (Spinacia oleracea L.) leaves
}

\author{
D. Rydzyński ${ }^{1,2} \cdot$ A. I. Piotrowicz-Cieślak ${ }^{1}$ H. Grajek ${ }^{2}$ D. J. Michalczyk ${ }^{1}$
}

Received: 22 January 2018 / Revised: 23 November 2018 / Accepted: 26 November 2018 / Published online: 3 December 2018

(c) The Author(s) 2018

\begin{abstract}
Degradation of chlorophyll was studied in leaves of spinach grown in soil containing cadmium and tetracycline, based on spectroscopic measurements and biochemical analyses of plant extracts. It was shown that plant exposure to the highest levels of tetracycline and cadmium resulted in $64 \%$ and $68 \%$, respectively, reduction in chlorophyll content. The chlorophyll degradation rate constants were determined, and they were found to increase with increasing doses of tetracycline and cadmium. The rate constant of chlorophyll degradation by tetracycline ranged from $k=960 \mathrm{M}^{-1}$ day ${ }^{-1}$ to $k=2180 \mathrm{M}^{-1}$ day $^{-1}$, and the rate constant of chlorophyll degradation by cadmium ranged from $k=1130 \mathrm{M}^{-1}$ day $^{-1}$ to $k=2580 \mathrm{M}^{-1}$ day $^{-1}$, depending on dose. Plant stress responses to tetracycline are much stronger than to cadmium, as is visible from the activity of guaiacol peroxidase and catalase. However, phytotoxicity of cadmium, measured by the rate of chlorophyll degradation and enzyme activities, is much higher compared to tetracycline. The spectroscopic measurements were taken 10 days after tetracycline and cadmium were added to the reagent grade chlorophyll which was used at the concentration of chlorophyll in plants. Changes in absorption and fluorescence spectra are likely to result from removal of magnesium from the chlorophyll molecule, and thus they indicate the formation of pheophytin. Cadmium, on the other hand, is probably bound into the chlorophyll molecule, substituting its magnesium.
\end{abstract}

Keywords Absorption spectra $\cdot$ Fluorescence spectra $\cdot$ Tetracycline contents $\cdot$ Cadmium contents $\cdot$ Enzymes activity

$\begin{array}{ll}\text { Abbreviations } \\ \text { TC } & \text { Tetracycline } \\ \text { Chl } & \text { Chlorophyll } \\ \text { rgChl } & \text { Reagent grade chlorophyll } \\ k & \text { Reaction rate constant }\end{array}$

Editorial responsibility: M. Abbaspour.

\section{A. I. Piotrowicz-Cieślak}

acieslak@uwm.edu.pl

1 Department of Plant Physiology, Genetics and Biotechnology, Faculty of Biology and Biotechnology, University of Warmia and Mazury in Olsztyn, Oczapowskiego 1A, 10-718 Olsztyn, Poland

2 Department of Physics and Biophysics, Faculty of Food Science, University of Warmia and Mazury in Olsztyn, Oczapowskiego 4, 10-719 Olsztyn, Poland

\section{Introduction}

To obtain high food quality, crops must be grown in soil that is free of toxic substances. These include antibiotics, and they can occur naturally, in very low quantities, in arable soils (Sanitá di Toppi and Gabbrielli 1999). Currently, however, industrial and agricultural pollution, widespread in the environment, is the main source of antibiotics, as well as toxic metals. Cadmium $(\mathrm{Cd})$ is the most frequently released metal (Wagner 1993), and tetracycline is the most often released antibiotic (US EPA 2012).

Cadmium comes mostly from phosphate fertilisers and wastewater sludge used for soil enrichment. Some fertilisers contain up to $300 \mathrm{Cd} \mathrm{mg} / \mathrm{kg}$ (Alloway and Steinnes 1999). According to Roberts (2014), the cadmium content of phosphate fertilisers used in the USA can exceed $150 \mathrm{Cd} \mathrm{mg} / \mathrm{kg}$. Considering that phosphate fertilisers are applied in typical production systems of cereals, vegetables and root crops at $70,133,176 \mathrm{~kg} / \mathrm{ha}$, over $25,000 \mathrm{Cd} \mathrm{mg} / \mathrm{ha}$ is introduced into the soil every year. Soil monitoring carried out by the Institute of Soil Science and Plant Cultivation (IUNG, Puławy, Poland) shows that the highest cadmium concentration in 
arable areas in Poland reached $67.98 \mathrm{mg} / \mathrm{kg}$ in 2015 and in 2000 it exceeded $90 \mathrm{mg} / \mathrm{kg}$ (90.78 mg/kg; IUNG 2017). In fruit tree production antibiotics are used directly, when needed, for eradication of bacterial diseases like fire blight (Stockwell and Duffy 2012); however, the scale of this antibiotic use in orchards is very limited (only $0.12 \%$ of the total antibiotics use in agriculture). A large part (from 10 to $90 \%$ ) of antibiotics, including tetracycline, commonly applied in animal production, return to the environment as they are excreted from the animal bodies in an unchanged form or as active metabolites. They have been found in soil when manure was used from animals subjected to antibiotic therapy. The contents of soil antibiotics in arable lands range from 0.1 to $1420 \mathrm{mg} / \mathrm{kg}$ of soil (Pan and Chu 2016). Both cadmium and tetracycline are toxic to crops, and they decrease the crop nutritional value. They are taken up by roots and absorbed by xylem; they are transported to the aboveground parts of plants (Wang et al. 2015; Margas et al. 2016). Although $\mathrm{Cd}$ is a non-reducing metal, it is toxic to the majority of crops at very low concentrations, above of 5-10 Cd ng/g dry weight of leaves (Sanitá di Toppi and Gabbrielli 1999). Only some plants, called Cd-hyperaccumulators, can safely accumulate considerable amounts of Cd (up to $100 \mathrm{Cd} \mu \mathrm{g} / \mathrm{g}$ of dry weight of leaves; Zhao et al. 2002).

It has been repeatedly demonstrated that both antibiotics (Margas et al. 2016; Zhao et al. 2002; Rydzyński et al. 2017) and cadmium (Küpper et al. 2006) inhibit photosynthesis and contribute to the generation of reactive oxygen species (ROS) (Andresen and Küpper 2013). ROS cannot be formed directly in the Fenton or Haber-Weiss reaction (Wardman and Candeias 1996), but they may arise indirectly, due to the impairment of photosynthesis or respiration. Plants employ a wide range of reactions for defense against ROS, which include the activation of oxidative enzymes, such as superoxide dismutase, peroxidase, and catalase, as well as accumulation of low molecular mass antioxidants (ascorbic acid, reduced glutathione or carotenoids) (Gill and Tuteja 2010; Gill et al. 2012). Moreover, cadmium and tetracycline reduce the content of photosynthetic pigments and thus reduce the plant growth rate and initiate chlorosis (Margas et al. 2016; Marcano et al. 2009). Reduction in chlorophyll (Chl) content in leaves adversely affects plant physiology. This pigment, however, is not only indispensable for plants, but it also has favorable actions on humans ingesting it, due to its antihyperglycaemic and antihyperlipidemic properties (Patar et al. 2016). In humans, food chlorophyll may limit the bioavailability of aflatoxin (Jubert et al. 2009). The beneficial effects of chlorophyll involve the protection of DNA from oxidation and protection of lipids from peroxidation. Both these deteriorative activities result from a reduction in ROS and chelation of metal ions (Lanfer-Marquez et al. 2005; Suparmi et al. 2016). The porphyrin ring in chlorophyll acts as an interceptor molecule, inactivating mutagens by direct binding to their planar, cyclic molecules (Tachino et al. 1994; Chernomorsky et al. 1999). Carcinogens can also be inactivated this way. Moreover, the bioavailability of the complexes formed by chlorophyll and carcinogenic/ mutagenic molecules is very limited as they are too large to be absorbed from the intestines.

Chlorophyll can be effective even if it is not directly involved in blocking carcinogenic molecules (Chernomorsky et al. 1999). Another potential anticancer effect of chlorophyll is related to its antioxidative properties (LanferMarquez et al. 2005; Endo et al. 1985; Hsu et al. 2005) and the ability to chelate antioxidants. A decrease in the leaf chlorophyll content results in a change of leaf color and thus decreases the market quality of fresh fruit and leaves. Numerous studies of chlorophyll degradation by various technological processes have been conducted. Changes in color and degradation of chlorophyll, e.g., during heating or freezing, are associated with pheophytinization, epimerisation, pyrolysis, hydroxylation and oxidation (Mangos and Berger 1997). However, chlorophyll loss in plants may result not only from technological processing but also from environmental pollution.

In this paper, for the first time, a comparison is made between plant reactions to tetracycline and cadmium as soil contaminants. These substances were selected considering that cadmium is one of the best documented soil pollutants, while the knowledge of the effects of soil tetracycline (and other drugs) is very incomplete. We used spectroscopic methods-measurements of both chlorophyll absorption and fluorescence-to analyze the changes in chlorophyll contents. Moreover, the activities of oxidative stress enzymes (catalase and guaiacol peroxidase) were determined.

\section{Materials and methods}

\section{Materials}

Spinach (Spinacia oleracea L.) cv. Matador seeds used in this study were purchased from a grocery. Tetracycline, cadmium sulfate and most other reagents were from Sigma.

\section{Methods}

\section{Seedling growth and chlorophyll extraction}

The plants were grown for 20 days in a greenhouse under controlled conditions (temp. $23 / 19^{\circ} \mathrm{C}$, day/night; photoperiod $16 / 8 \mathrm{~h}$ day/night; light intensity $3 \mathrm{kLx}$ ) after sowing in pots with $500 \mathrm{~g}$ of soil (sand, vermiculite, peat 1:0.3:1, $\mathrm{v} / \mathrm{v} / \mathrm{v})$. One plant was grown in each pot. Twenty-day-old spinach seedlings, $8-10 \mathrm{~cm}$ tall (with four leaves), were selected and treated with aqueous solutions of tetracycline 
and cadmium sulfate, using 3, 45 and $90 \mathrm{mg}$ of the compound $/ \mathrm{kg}$ of soil, with water as a control. Analyses were carried out 2, 4, 7 and 10 days after the toxic substances had been applied. Dry and fresh weights were also determined at each time of analysis.

Chlorophyll was extracted from spinach leaves $(300 \mathrm{mg}$ ) with $5 \mathrm{ml}$ methanol. The homogenate thus obtained was centrifuged at room temperature at $1500 \mathrm{~g}$. The extract was then fivefold diluted and used for spectrophotometric and fluorometric analyses.

\section{Absorption and fluorescence characteristics of chlorophyll degradation}

Chlorophyll was extracted from spinach leaves with methanol ( $5 \mathrm{ml} / 300 \mathrm{mg}$ leaf fresh weight) using a porcelain mortar and pestle, at room temperature. The extracts were centrifuged at $1500 \mathrm{~g}$. The pellets were washed with the solvent five times, and the methanol solutions from all extraction stages were combined. Thus, obtained chlorophyll solutions were used for spectroscopic analyses.

The Carry 300 UV-Visible Spectrophotometer (Varian, Inc.) was used for measurements of absorption spectra, while the steady-state fluorescence spectra were measured with the Carry Eclipse Fluorescence Spectrophotometer (Varian, Inc.) applying the right-angle geometry.

The excitation wavelength $\lambda_{\text {exc }}=650 \mathrm{~nm}$, the excitation slit width and the emission slit width $2.5 \mathrm{~nm}$ and $5 \mathrm{~nm}$, respectively, were used.

The Lambert-Beer law was applied to calculate the chlorophyll concentration, taking $\varepsilon=66,600 \mathrm{M}^{-1} \mathrm{~cm}^{-1}$ as molar extinction coefficient for chlorophyll in methanol at $\lambda=665.7 \mathrm{~nm}$, according to Seely and Jensen (1965).

To obtain the chlorophyll absorption spectra, extracts from five independent plants were measured for each soil tetracycline and cadmium concentration.

A commercial chlorophyll from Sigma chemical company [described below as reagent grade chlorophyll ( $\mathrm{rgChl})$ ] was also used for the absorption and fluorescence measurements. It was dissolved in methanol, and $\mathrm{TC}$ or $\mathrm{CdSO}_{4}$ was added to obtain their final concentrations corresponding to the levels detected in plants.

The decreases in plant chlorophyll concentrations resulting from three doses of applied TC and Cd, observed within 10 days, were used to study the kinetics of chlorophyll degradation reaction, the reaction order and reaction rate constant.

\section{Catalase activity}

The catalase activity in spinach leaves was determined spectrophotometrically. The leaves (500 $\mathrm{mg}$ fresh weight) were homogenized with a porcelain mortar and pestle in an extraction buffer containing $\mathrm{K}_{2} \mathrm{HPO}_{4} / \mathrm{KH}_{2} \mathrm{PO}_{4}(0.05 \mathrm{M}$, pH 7.8), EDTA (Sigma-Aldrich; $0.1 \mathrm{mM}$;), Triton X-100 [Sigma-Aldrich; 0.5\% (v/v)], polyvinylpyrrolidone [PVP; Sigma-Aldrich; $1 \%(\mathrm{w} / \mathrm{v})]$. The homogenization was carried out on ice, and the extracts were centrifuged at $4{ }^{\circ} \mathrm{C}$ for $20 \mathrm{~min}$ at $18,000 \mathrm{~g}$. Protein contents in supernatants were measured according to Bradford (1976). The catalase activity was measured in a reaction mixture containing $50 \mathrm{mM}$ phosphate buffer (pH 7), $25 \mu \mathrm{l}$ of freshly prepared $10 \mathrm{mM}$ $\mathrm{H}_{2} \mathrm{O}_{2}$ and $50 \mu \mathrm{l}$ of protein extract, in a final volume of $1 \mathrm{ml}$. The reaction was started by adding the extract, and the changes in absorbance were measured for $100 \mathrm{~s}$ at the wavelength $\lambda=240 \mathrm{~nm}$ and $25^{\circ} \mathrm{C}$ temperature. One unit of enzyme activity [U] corresponded to the reduction of $1 \mu \mathrm{mol}$ $\mathrm{H}_{2} \mathrm{O}_{2}$ by the extract during $100 \mathrm{~s}$ under conditions given above.

\section{Guaiacol peroxidase activity}

Samples of spinach leaves (500 $\mathrm{mg}$ fresh weight) were homogenized on ice in an extraction buffer containing: $0.1 \mathrm{mM}$ Tris-HCl (Sigma-Aldrich), polyvinylopyrrolidone (Sigma-Aldrich; 8.75\%), KCI (Stanlab PPH; 0.1 M), Triton X-100 (Sigma-Aldrich; 0.28\%). The extracts were centrifuged for $20 \mathrm{~min}$ at $18,000 \mathrm{~g}, 4{ }^{\circ} \mathrm{C}$. The protein contents of extracts were measured with Bradford (1976) method. Enzyme activity was determined with a Ceclor spectrophotometer (serial number CE2021 2000) at $\lambda=470 \mathrm{~nm}$, $25^{\circ} \mathrm{C}$. The reaction mixture contained $2 \mathrm{ml} 0.1 \mathrm{M} \mathrm{KH}_{2} \mathrm{PO}_{4} /$ $\mathrm{K}_{2} \mathrm{HPO}_{4}$ (Chempur; pH 5), $25 \mu \mathrm{l} 0.06 \% \mathrm{H}_{2} \mathrm{O}_{2}$ (Chempur), $100 \mu \mathrm{l} 1 \%$ guaiacol ( $O$-methoxyphenol, Sigma-Aldrich) and $50 \mu \mathrm{l}$ protein extract. One unit of activity [U] corresponded to the oxidation of $1 \mu \mathrm{mol} \mathrm{H}_{2} \mathrm{O}_{2}$ during 1 min by $1 \mu \mathrm{g}$ protein.

\section{Tetracycline content}

The content of TC in 20-day-old seedlings (after 2, 4, 7 and 10 days long antibiotic treatment) was determined. Plant sap was squeezed from fresh plant material with a mortar and pestle. Leaves $(500 \mathrm{mg})$ were homogenized with $1 \mathrm{ml}$ of methanol containing $20 \mu \mathrm{g}$ 7-chlortetracycline hydrochloride (Sigma) as internal standard and centrifuged for $10 \mathrm{~min}$ at $13,200 \mathrm{~g}$. The obtained supernatant was transferred onto nylon filters (mesh size 0.22) (Sigma). For all extractions SPE, cartridges Chromabond ${ }^{\circledR}$ Easy, $3 \mathrm{ml} / 200 \mathrm{mg}$, Macherey-Nagel, Dtiren, Germany, were used. SPE cartridges were rinsed with methanol and after loading with plant saps were eluted with $250 \mu \mathrm{l}$ methanol. Tetracycline content in seedlings was analyzed by HPLC (Water Alliance 2695) according to Pailler et al. (2009) with small modifications by Rydzyński et al. (2017). 


\section{Cadmium content}

The content of cadmium in spinach leaves was determined using the graphite furnace atomic absorption spectrometry (GFAAS) and flame atomic absorption spectrophotometry (FAAS) methods. Leaf samples were dried to a constant weight. They were then processed in a microwave mineraliser. The samples were transferred quantitatively to Teflon bombs, and $\mathrm{HNO}_{3}$ and $\mathrm{H}_{2} \mathrm{O}_{2}$ were added. A blank consisting of the reagents used in the procedure was also mineralized. Samples were next diluted and centrifuged for $10 \mathrm{~min}$ at $5000 \times g$. The supernatant was used for further assays in the Sollar M device. The FAAS technique was applied on samples containing cadmium at the level above $0.5 \mathrm{ppm}$ and GFAAS with a graphite couvette where samples containing less than 0.5 ppm cadmium were analyzed.

\section{Statistical analysis}

Tukey's post hoc test ( $p \leq 0.01)$ was applied to evaluate differences between controls and treatments using Statistica 6.0 program.

Reaction kinetics was described using the equation:

$\frac{1}{C}=\frac{1}{C_{0}}+k t$,

where $C=$ substrate concentration after time $t, C_{0}=$ initial substrate concentration $k=$ rate constant of chlorophyll degradation.

The GraphPad Prism version 6 program (GraphPad Prism Software, San Diego CA, USA) was applied to perform linear regression. The calculated results are given as a slope $(k) \pm$ standard error (SEM). Goodness of fit $R^{2}$ has been shown. The complex standard uncertainties of function $f(t)=\frac{1}{C}$ were calculated according to the equation:

$u(f)=\sqrt{\left(\frac{\partial f}{\partial C}\right)^{2} u^{2}(C)}$,

where $u(C)$-standard uncertainty of concentration. $u(C)=\mathrm{SD}$ (standard deviation), which was determined for all measurements.

\section{Results and discussion}

\section{Absorption and fluorescence characteristics of chlorophyll degradation}

Chlorophyll is one of the main plant metabolites. It is indispensable for photosynthesis, and on the other hand, it has great value for animal/human consumers of plants as it was demonstrated to possess anticancer properties (Simonich et al. 2007). Chlorophyllin, a chlorophyll derivative, inhibits proliferation of cancer cells and induces the expression of chemokines (Kang et al. 2013). Phenophorbide and tetrapyrol, which are products of chlorophyll metabolism, can be conjugated to anticancer drugs and enhance their efficiency (You et al. 2011). They have also been shown to inhibit metastases (Weagle et al. 2010). It seems, therefore, reasonable to assume that each environmental factor that lowers the chlorophyll content in plants is detrimental for both plant growth and plant nutritive/nutraceutical properties. This paper documents the effects of cadmium (a well-known soil pollutant), and tetracycline (a drug recently described as important pollutant of some soils) on chlorophyll content in spinach leaves. We used physical methods-absorption and fluorescence measurements-to assess the changes in chlorophyll content.

Absorption spectra of chlorophyll isolated from the leaves of spinach grown in a soil containing $\mathrm{TC}$ and $\mathrm{Cd}$ at the following concentrations: 3,45 and $90 \mathrm{mg} / \mathrm{kg}$ of soil were measured. The decreases in chlorophyll absorption at 2, 4, 7 and 10 days after treatments with antibiotic and cadmium sulfate are shown in Fig. 1. The figure shows that both the dose and the period of plant growth in contaminated soil had a strong impact on $\mathrm{Chl}$ content in plants. After 10 days, the absorbance of $\mathrm{Chl}$, from plants exposed to $\mathrm{TC}$ at the dose of $3 \mathrm{mg} / \mathrm{kg}$ soil, dropped from $A=1.05$ (measured in control spinach) to $A=0.575$, but at the dose $90 \mathrm{mg} / \mathrm{kg}$ of soil the drop of absorbance was higher from $A=1.05$ to $A=0.376$. In spinach exposed to $\mathrm{Cd}$ for 10 days, the drop of absorbance was stronger, down to $A=0.530$ (at the dose $3 \mathrm{mg} / \mathrm{kg}$ of soil) and to $A=0.326$ with the Cd dose $90 \mathrm{mg} \mathrm{kg}^{-1}$.

The chlorophyll molar concentration and its percent decrease in the leaves of spinach plants affected by TC and $\mathrm{Cd}$ concentration and time of its action (period of plant growth after soil application of TC and Cd) were calculated (Table 1).

Chlorophyll concentration $(C)$ in control leaves (from plants growing in the uncontaminated soil) was $C=7.88 \times 10^{-5} \mathrm{M}$, and decreased to $C=4.32 \times 10^{-5} \mathrm{M}$, $C=3.39 \times 10^{-5} \mathrm{M}$ and $C=2.82 \times 10^{-5} \mathrm{M}$ with TC concentration doses 3,45 and $90 \mathrm{mg} / \mathrm{kg}$ of soil, respectively. On the other hand, after the application of cadmium, chlorophyll concentration drops within 10 days were greater: from the initial value of $C=7.88 \times 10^{-5} \mathrm{M}$ to $C=4.09 \times 10^{-5} \mathrm{M}$, $C=3.17 \times 10^{-5} \mathrm{M}$ and $C=2.55 \times 10^{-5} \mathrm{M}$ with $\mathrm{Cd}$ doses of 3,45 and $90 \mathrm{mg} / \mathrm{kg}$ of soil, respectively. Table 1 also shows the percentage decrease in chlorophyll concentration. After 10 days at a TC dose of $90 \mathrm{mg} / \mathrm{kg}$ of soil, the $\mathrm{Chl}$ decreased approximately three times, thus leaving only $36 \%$ of the initial chlorophyll content in spinach. However, after Cd application at a dose $90 \mathrm{mg} / \mathrm{kg}$ of soil, 
Fig. 1 Absorption spectra of Chl isolated from leaves of spinach grown for 2, 4, 7 and 10 days in a soil containing TC and $\mathrm{Cd}$ in the following concentrations: $3,45,90 \mathrm{mg} \mathrm{kg}^{-1}$ of soil. $\left(0 \mathrm{mg} \mathrm{kg}^{-1}\right.$ of soil is a control for Chl from plants grown in a soil with no $\mathrm{TC}$ and $\mathrm{Cd}$ )
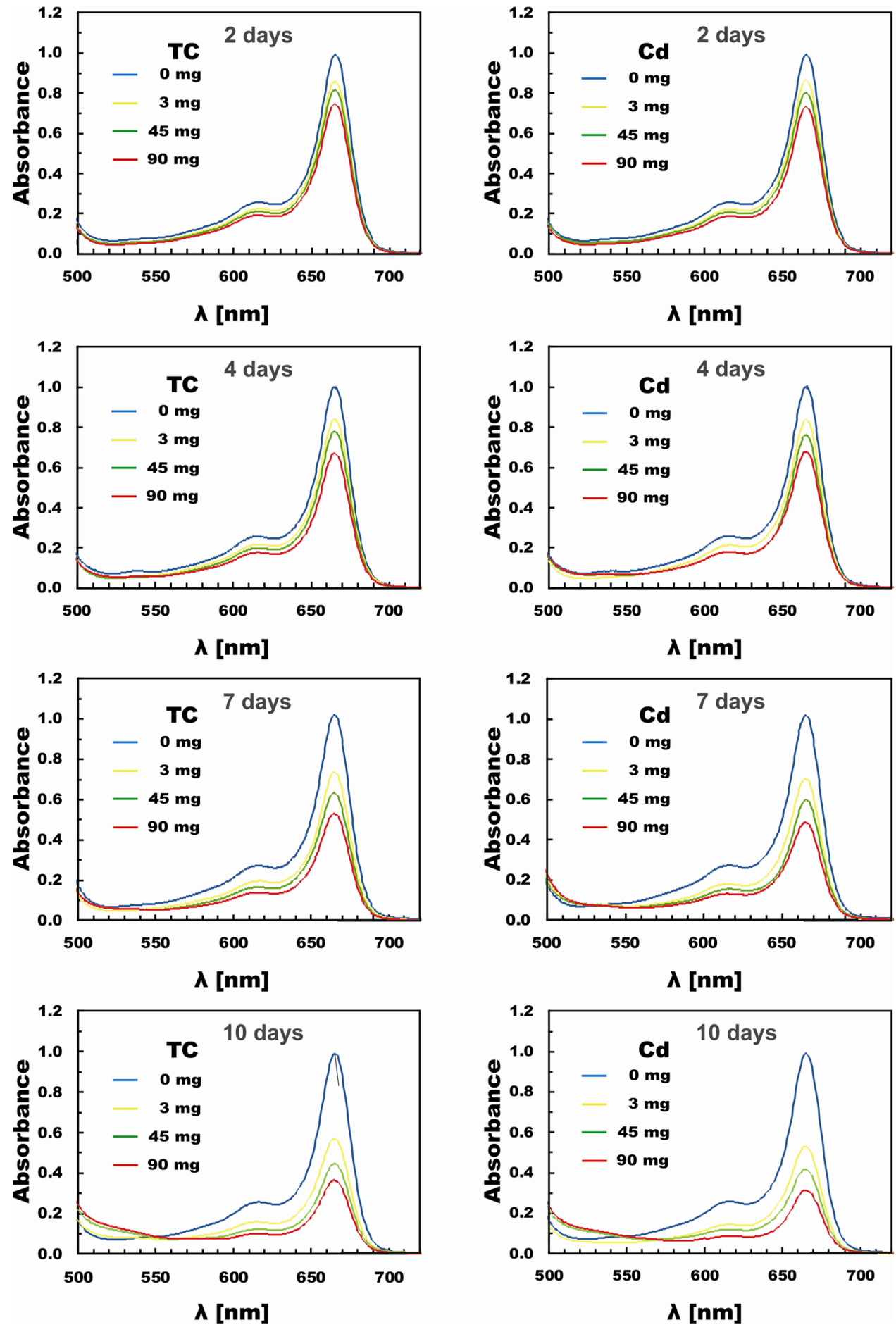

only $32 \%$ of spinach leaf chlorophyll remained (Table 1). Thus, in spinach leaves of plants treated with cadmium a slightly greater degradation of chlorophyll was observed. Cadmium caused a 68\% drop in chlorophyll content and tetracycline a $64 \%$ reduction. The fluorescence spectra of chlorophyll obtained from spinach leaves growing in TC and Cd-contaminated soil are shown in Fig. 2.
After 4 days of plant treatment with TC, the fluorescence spectra were not shifted to shorter wavelengths. On the other hand, when using $\mathrm{Cd}$, we could see a slight shift in the short-wave direction. After 10 days there was a definite shift of the maximum fluorescence spectrum by $4 \mathrm{~nm}$ : from $679 \mathrm{~nm}$ (for chlorophyll from leaves of plants not treated with TC) to $675 \mathrm{~nm}$ (for plants subjected 
Table 1 Chl concentration $(C[\mathrm{M}] \pm$ standard deviation, SD) and its percent decrease $(C[\%] \pm \mathrm{SD})$ (in the examined samples compared to the control) in spinach leaves grown for 10 days in the soil containing different amounts of TC and Cd: $3,45,90 \mathrm{mg} \times \mathrm{kg}^{-1}$ of soil

\begin{tabular}{|c|c|c|c|c|c|c|}
\hline \multirow{2}{*}{$\begin{array}{l}\text { Dose } \\
\text { Day }\end{array}$} & \multicolumn{2}{|l|}{$3 \mathrm{mg} \times \mathrm{kg}^{-1}$} & \multicolumn{2}{|l|}{$45 \mathrm{mg} \times \mathrm{kg}^{-1}$} & \multicolumn{2}{|l|}{$90 \mathrm{mg} \times \mathrm{kg}^{-1}$} \\
\hline & $C \times 10^{-5}(\mathrm{M})$ & $\%$ & $C \times 10^{-5}(\mathrm{M})$ & $\%$ & $C \times 10^{-5}(\mathrm{M})$ & $\%$ \\
\hline \multicolumn{7}{|l|}{$\mathrm{TC}$} \\
\hline 0 & $7.88 \pm 0.051$ & $100 \pm 0.64$ & $7.88 \pm 0.051$ & $100 \pm 0.64$ & $7.88 \pm 0.051$ & $100 \pm 0.64$ \\
\hline 2 & $6.45 \pm 0.040$ & $82 \pm 0.51$ & $6.16 \pm 0.088$ & $78 \pm 1.11$ & $5.61 \pm 0.073$ & $71 \pm 0.92$ \\
\hline 4 & $6.25 \pm 0.052$ & $79 \pm 0.66$ & $5.84 \pm 0.104$ & $74 \pm 1.32$ & $5.04 \pm 0.061$ & $64 \pm 0.77$ \\
\hline 7 & $5.45 \pm 0.068$ & $68 \pm 0.85$ & $4.56 \pm 0.078$ & $58 \pm 0.99$ & $3.79 \pm 0.095$ & $48 \pm 1.20$ \\
\hline 10 & $4.32 \pm 0.049$ & $55 \pm 0.62$ & $3.39 \pm 0.093$ & $43 \pm 1.18$ & $2.82 \pm 0.079$ & $36 \pm 1.01$ \\
\hline \multicolumn{7}{|l|}{$\mathrm{Cd}$} \\
\hline 0 & $7.88 \pm 0.051$ & $100 \pm 0.64$ & $7.88 \pm 0.051$ & $100 \pm 0.64$ & $7.88 \pm 0.051$ & $100 \pm 0.64$ \\
\hline 2 & $6.51 \pm 0.076$ & $83 \pm 0.97$ & $6.12 \pm 0.085$ & $77 \pm 1.07$ & $5.51 \pm 0.135$ & $70 \pm 1.71$ \\
\hline 4 & $6.23 \pm 0.098$ & $79 \pm 1.25$ & $5.73 \pm 0.234$ & $73 \pm 2.98$ & $4.95 \pm 0.097$ & $63 \pm 1.23$ \\
\hline 7 & $5.11 \pm 0.094$ & $68 \pm 1.25$ & $4.28 \pm 0.045$ & $54 \pm 0.57$ & $3.98 \pm 0.080$ & $44 \pm 0.89$ \\
\hline 10 & $4.09 \pm 0.117$ & $50 \pm 1.42$ & $3.17 \pm 0.011$ & $40 \pm 0.14$ & $2.55 \pm 0.020$ & $32 \pm 0.25$ \\
\hline
\end{tabular}

to tetracycline at $90 \mathrm{mg} / \mathrm{kg}$ soil) and $5 \mathrm{~nm}$ : from 679 to $674 \mathrm{~nm}$ in plants subjected to $\mathrm{Cd}$ treatment. Also, the intensity of fluorescence spectra was reduced and this effect was stronger in $\mathrm{Cd}$ than TC treatments. A similar shift of fluorescence spectra $(5 \mathrm{~nm})$ was observed with $\mathrm{Chl}$ from leaves of lupin growing in TC contaminated soil TC (Rydzyński et al. 2017). The fluorescence spectra shifts confirm the formation of chlorophyll degradation product under the action of TC and Cd on plants.

Many physiological-biochemical processes occur in plants and are modified by cadmium: plant growth (Yang et al. 2018), gene expression (Zhang et al. 2018a, b), protein content (Chen et al. 2018), amino acid metabolism (Singh et al. 2012) or antioxidant enzyme activity (Yousefi et al. 2018). To investigate the direct effects of tetracycline and cadmium on chlorophyll, we included analyses of reagent grade $\mathrm{Chl}$ (rgChl; purchased from Sigma) in addition to $\mathrm{Chl}$ extracted from plants in our experiments. RgChl with TC solutions and $\mathrm{RgChl}$ with $\mathrm{Cd}$ were prepared. The concentrations of $\mathrm{TC}$ and $\mathrm{Cd}$ in these solutions were equal to those found in plants after application of TC/Cd at $90 \mathrm{mg} / \mathrm{kg}$ of soil. Measurements of absorption and fluorescence spectra were carried out after 10 days — using the same duration of $\mathrm{TC}$ and $\mathrm{Cd}$ action on chlorophyll as in plants.

The changes in absorption and fluorescence spectra after 10 days for rgChl treated with TC are shown in Fig. 3a, b. The absorption spectra showed the appearance of additional bands, which indicate the formation of pheophytin. These bands could not be observed in Fig. 1 with Chl extracted from spinach, due to the overlapping of the long wave part of the absorption spectrum of carotene with the absorption spectrum of chlorophyll (Fig. 4). However, the increase in absorbance in the range 500-550 $\mathrm{nm}$ seen in curve 1 (Fig. 4, TC dose $90 \mathrm{mg} / \mathrm{kg}$ of soil) may indicate the presence of two hidden bands of pheophytin. The results obtained with rgChl (Fig. 3a) indicate that tetracycline probably causes the removal of magnesium atom from chlorophyll and the formation of pheophytin.

This is probable, because as it was demonstrated by Schneider et al. (2003) tetracycline readily reacts with magnesium ions binding them into its rings in a few positions. The fluorescence spectra for the rgChl solution treated with TC showed the same $4 \mathrm{~nm}$ shift toward the shorter wavelengths as was seen with chlorophyll extracted from leaves of TCtreated spinach (at the $90 \mathrm{mg}$ dose $/ \mathrm{kg}$ of soil).

The absorption spectra for $\mathrm{rgChl}$ treated with $\mathrm{Cd}$ are shown in Fig. 5a. After a 10-day exposure to cadmium the spectra shifted by $9 \mathrm{~nm}$ toward the shorter wavelengths from 665 to $656 \mathrm{~nm}$, but the absorption bands typical of pheophytin at $506 \mathrm{~nm}$ and $536 \mathrm{~nm}$ were not observed. This indicates that chlorophyll is not converted to pheophytin under the influence of $\mathrm{Cd}$. We state, therefore, similarly to other authors who showed the formation of metal-chlorophyll complexes that cadmium eliminates magnesium from chlorophyll and replaces it in the central position of the porphirine ring. Many papers on metaloporphirins have been published (Kang et al. 2018; Bechaieb et al. 2016b; Zvezdanović et al. 2014; Küpper et al. 2006). Recently, based on quantum chemical calculations (with Gaussian 09 program, using the density functional theory DFT at B3LYP level) the chemical structures of metaloporphirins (with $\mathrm{Hg}$, $\mathrm{Pb}$ and $\mathrm{Cd}$ ) were described and the reaction of metaloporphirin formation was postulated (Bechaieb et al. 2016a).

The formation of a new compound, a Cd-containing chlorophyll, was also revealed by a strong shift of fluorescence spectra (Fig. 5b) toward short wavelengths, from 678 to $668 \mathrm{~nm}$. However, in the case of $\mathrm{Chl}$ extracted from leaves of Cd-treated spinach, the shift of fluorescence spectrum was $5 \mathrm{~nm}$ (Fig. 2) and in absorption spectrum it was only $1.5 \mathrm{~nm}$ (Fig. 1, for Cd 10 days treatment). A small shift of chlorophyll absorption spectra as a result of $\mathrm{Mg}$ replacement with Cd was also noticed by Küpper et al. (1996) in 
Fig. 2 Fluorescence spectra of Chl isolated from leaves of spinach grown for 2, 4, 7 and 10 days in a soil containing $\mathrm{TC}$ and $\mathrm{Cd}$ in the following concentrations: $3,45,90 \mathrm{mg} \mathrm{kg}^{-1}$ of soil. $\left(0 \mathrm{mg} \mathrm{kg}^{-1}\right.$ of soil is a control for $\mathrm{Chl}$ from plants grown in a soil with no antibiotic and $\mathrm{Cd}$ )
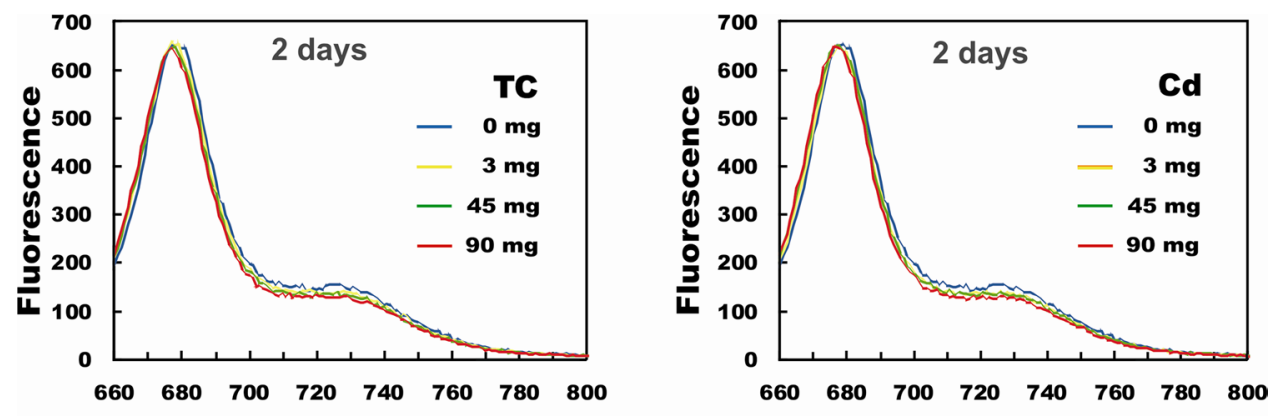

$\Lambda$ [nm]
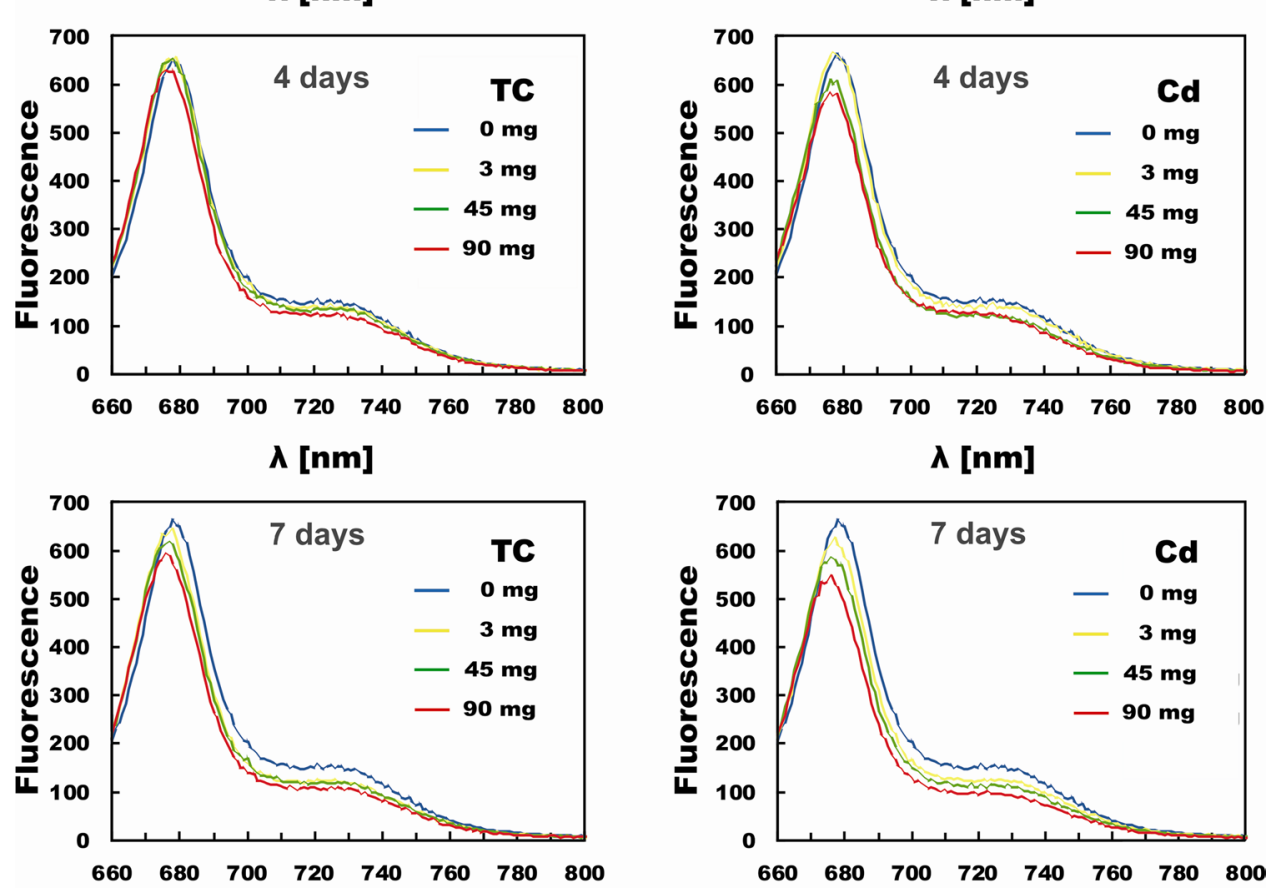

$\lambda[\mathrm{nm}]$

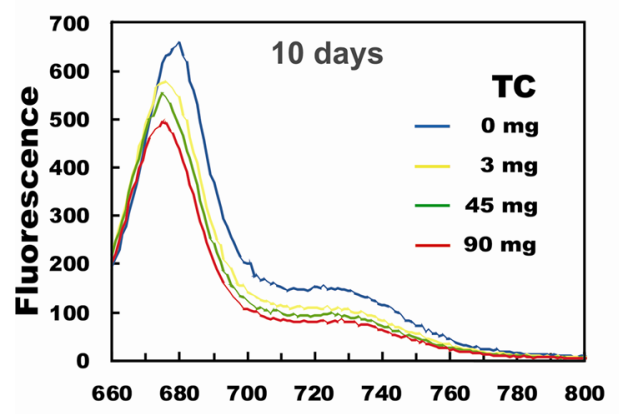

$\Lambda$ [nm]

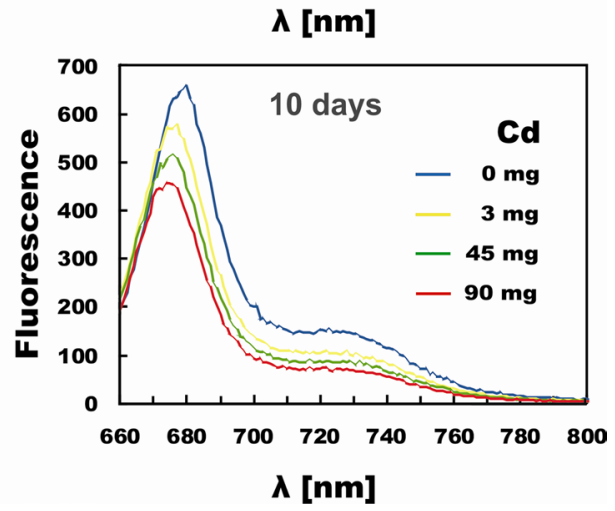

their in vitro studies on the effect cadmium on chlorophyll isolated from grass foliage. These shifts were: $3 \mathrm{~nm}$ for $\mathrm{Chl}$ $a$ and $1 \mathrm{~nm}$ for $C h l b$.

The absorption spectrum of chlorophyll, both isolated from leaves (Fig. 1) and rgChl (Fig. 4), was not shifted under the influence of tetracycline, which indicates that tetracycline did not change the energy of excited state S1 (singlet state) of chlorophyll. On the other hand, a big drop (by up to
64\%) in the quantity of absorbed light (Figs. 1, 4), caused by a considerable drop in chlorophyll concentration, points to a severely diminished number of radiation quanta absorbed by the light harvesting antennae. Chlorophyll degradation by tetracycline, therefore, significantly limits the photosynthetic efficiency, which is in concordance with results of the measurements of leaf area, leaf dry and fresh mass. We should like to emphasize that the action of tetracycline 
Fig. 3 Changes in absorption (a) and fluorescence spectra (b) of $\mathrm{rgChl}$ and $\mathrm{rgChl}+\mathrm{TC}(\mathrm{rgChl}$ treated for 10 days with TC)
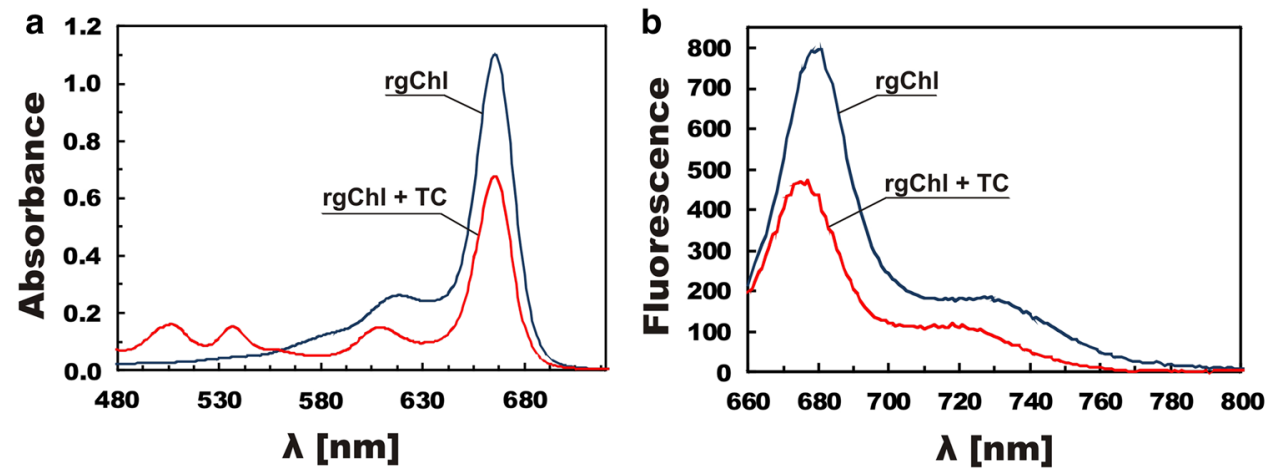

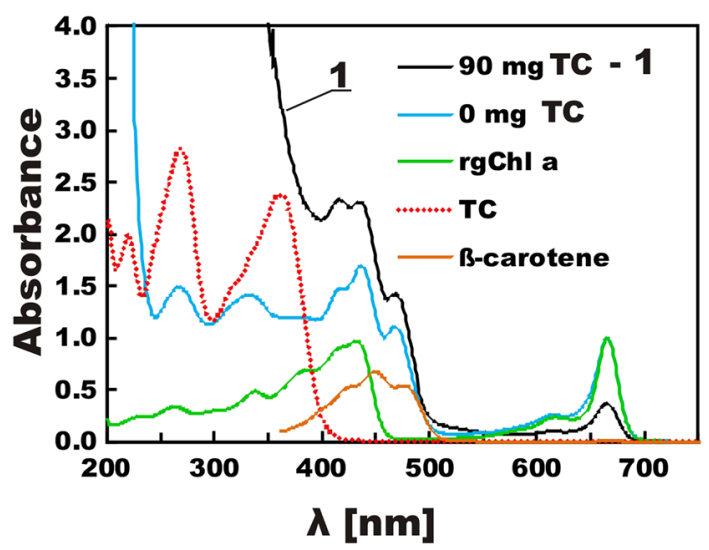

Fig. 4 Absorption spectrum of chlorophyll extracted from spinach 10 days (curve 1) after the application of TC ( $90 \mathrm{mg} \mathrm{kg}^{-1}$ soil), plotted against the background with the absorption spectra of the following samples: chlorophyll extracted from TC-nontreated spinach $(0 \mathrm{mg}$ TC), rgChl and $\beta$-carotene, TC tetracycline

results in shifts in fluorescence spectra (unlike the unshifted absorption spectra) toward the short wavelengths (Figs. 2, 4). This shift suggests that there is an increase in the energy of radiation quanta and the energy of resonance nonradiative transfer, which may disturb the energy migration within light harvesting antennae.
However, in the case of Cd, a large shift in the absorption spectra is observed which will disturb the S1 energy state of chlorophyll in the PSI and PSII. The large shift of absorption spectra involves changes of energy quanta, which can participate in the resonance energy transfer from the chlorophyll antennae to the reaction center. Such energy migration in PSI and PSII may prove impossible due to the different distribution of $0-0$ electronic transitions as a result of chlorophyll degradation, which can cause the breakdown of photosynthesis.

\section{Chlorophyll degradation kinetics}

In this paper, we studied the rate of chlorophyll degradation in plants under the influence of two detrimental factors: tetracycline and cadmium. The kinetics of chlorophyll degradation as a result of $\mathrm{TC}$ and $\mathrm{Cd}$ treatments was determined based on the chlorophyll concentration decrease as a function of time of spinach growth in soil containing TC and $\mathrm{Cd}$. Dependence of $\mathrm{Chl}$ concentration on time has been described by the kinetic equation $\frac{1}{C}=\frac{1}{C_{0}}+k t$, indicating that we are dealing with the second-order reaction both for the pheophytin formation reaction, induced by TC (Fig. 6a) and for the incorporation of $\mathrm{Cd}$ instead of $\mathrm{Mg}$ in Chl (Fig. 6b). Constant rates of $\mathrm{Chl}$ degradation increased with increasing antibiotic
Fig. 5 Changes in absorption (a) and fluorescence spectra (b) of $\mathrm{rgChl}$ and $\mathrm{rgChl}+\mathrm{Cd}(\mathrm{rgChl}$ treated for 10 days with $\mathrm{Cd}$ )
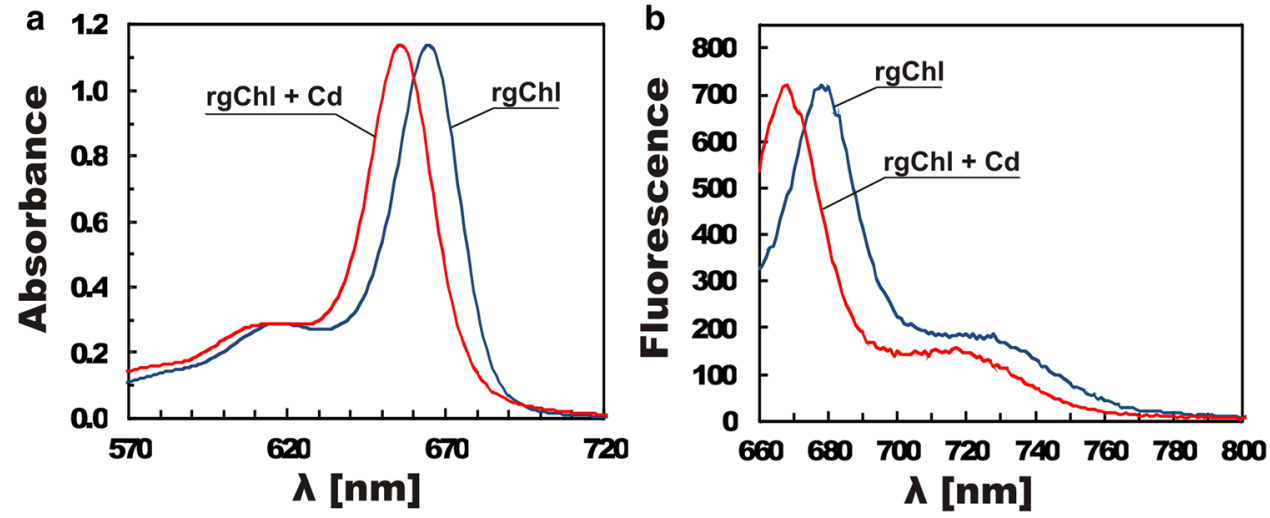
Fig. 6 The relationship between concentration of $\mathrm{Chl}$ extracted from antibiotic or cadmium affected plants $(3,45$ and $90 \mathrm{mg} \mathrm{kg}^{-1}$ of soil) and time of antibiotic action on plants. The following equation was used: $\frac{1}{C}=\frac{1}{C_{0}}+k t$

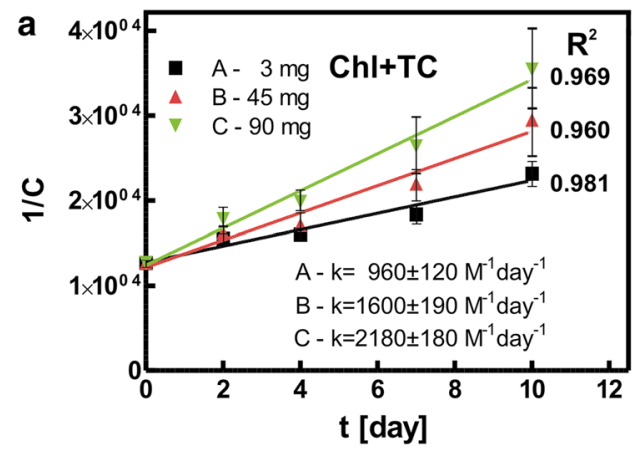

and $\mathrm{Cd}$ doses: for TC from $k=960 \mathrm{M}^{-1} \mathrm{day}^{-1}$ to $k=2180 \mathrm{M}^{-1} \mathrm{day}^{-1}$, and for $\mathrm{Cd}$ from $k=1130 \mathrm{M}^{-1}$ day $^{-1}$ to $k=2580 \mathrm{M}^{-1} \mathrm{day}^{-1}$. The constant of the rate of chlorophyll degradation was significantly higher in the case of $\mathrm{Cd}$ application compared to that of TC; for example, at the dose of $90 \mathrm{mg} / \mathrm{kg}$ of soil, it was $k=2580 \pm 230 \mathrm{M}^{-1} \mathrm{day}^{-1}$ and $k=2180 \pm 180 \mathrm{M}^{-1} \mathrm{day}^{-1}$ for $\mathrm{Cd}$ and TC, respectively. For comparison, the constant of chlorophyll degradation rate in lupin leaves growing in TC-treated soil is $2910 \pm 220 \mathrm{M}^{-1}$ day $^{-1}$ (Rydzyński et al. 2017) and is higher than for spinach (up to $2180 \pm 180 \mathrm{M}^{-1}$ day $^{-1}$; Fig. 6).

\section{The impact of TC and Cd on water balance in spinach leaves}

Decreasing amount of leaf chlorophyll, caused by TC and $\mathrm{Cd}$, can be a consequence of the reduction in leaf area. To verify the significance of this effect, the average area of a leaf blade was determined. The results are shown in Fig. 7a, b. Measurements of the leaves were started 2 days after TC and Cd were applied. The area of control leaves at the beginning of the experiment was $8.47 \mathrm{~cm}^{2}$, and it had increased by $0.32 \mathrm{~cm}^{2}$ in 10 days, which corresponded to a $3.65 \%$ increase. The average leaf area of plants growing for 10 days in soil containing the largest doses of TC and Cd increased only by $0.03 \mathrm{~cm}^{2}$ and by $0.04 \mathrm{~cm}^{2}$ in TC and $\mathrm{Cd}$ treatment, respectively. The smallest dose of $\mathrm{TC}$ and $\mathrm{Cd}$ acting for 10 days reduced the leaf blade area by $0.16 \mathrm{~cm}^{2}$ and $0.14 \mathrm{~cm}^{2}$, respectively. Therefore, during the 10 days of growth in soil containing $\mathrm{TC}$ and $\mathrm{Cd}$, the leaf area reduction did occur, but it was too small ( $4 \%$ at most) to account for a $68 \%$ reduction in leaf chlorophyll content. The fresh and dry weights of leaves were also determined (Fig. 7c, d).

The fresh weight of leaves growing on the second day in control conditions was $535 \mathrm{mg} / \mathrm{seedling}$, and it increased by $57 \mathrm{mg}$ by the 10th day. The fresh weight of leaves was lower by $107 \mathrm{mg}$ in TC-treated plants and by $168 \mathrm{mg}$ in Cd-plants, compared to the controls. The effect of $\mathrm{Cd}$ application on seedling fresh weight thus exceeded by $64.3 \%$ the effect caused by TC. A reduction in the fresh weight of leaves and an increase in dry weight of leaves were observed regardless of the time and dose of TC or Cd. The dry weight of leaves from plants which grew in control conditions, measured on the second day, was $8.23 \%$ by the tenth day. After 10 days on soil containing the largest dose of TC and Cd the leaf dry weight increased to $26.3 \%$ for TC and $33.6 \%$ for $\mathrm{Cd}$. Leaves of all plants growing with $\mathrm{Cd}$ had a greater dry weight than those growing with TC.

\section{Examination of $\mathrm{TC}$ and $\mathrm{Cd}$-caused stress and determination of the content of TC and Cd in spinach leaves}

In order to determine the influence of $\mathrm{TC}$ and $\mathrm{Cd}$ in soil on stress responses in plants, the activity of catalase and peroxidase in leaves of TC-affected plants (Fig. 8a) and Cd-affected plants (Fig. 8b) was examined. Contamination of soil with TC resulted in the activity of leaf catalase increased by $177 \%$ and activity of leaf peroxidase increased by $350 \%$ at the highest level of applied antibiotic. Xie et al. (2011) reported that TC at a dose of $25-300 \mathrm{mg} / \mathrm{l}$ increases the activity of catalase and peroxidase in roots of wheat by $528.5 \%$ and $629.7 \%$. As mentioned above, we did not observe such a large increase in the activity of these enzymes in our study. Di Marco et al. (2014) also reported an increase in the activity of antioxidative enzymes in plants growing on soil contaminated with antibiotics. On the other hand, in our experiments a considerable increase in the activity of antioxidative enzymes (by $194.6 \%$ for catalase and by $798.2 \%$ for peroxidase) was observed in Cd treatment rather than with TC.

The content of TC and Cd in leaves is shown in Fig. 8e, f. Leaves of spinach grown for 2 days in soil with the lowest level of TC contamination ( $3 \mathrm{mg} / \mathrm{kg}$ soil) accumulated TC $1.3 \mu \mathrm{g} / \mathrm{g}$ fresh mass, those isolated from plants grown for 2 days at the highest concentration contained $2.5 \mu \mathrm{g} / \mathrm{g}$ fresh mass, while after 10 days of growth leaves from the lowest and highest soil TC treatments contained 9.8 and $23 \mu \mathrm{g} \mathrm{TC} / \mathrm{g}$ fresh mass, respectively. Cd uptake was slower, although the soil concentrations of both pollutants (expressed as $\mathrm{mg} / \mathrm{kg}$ soil) were equal. Leaves from the lowest $\mathrm{Cd}$ treatment contained 0.05 and $0.13 \mu \mathrm{g} \mathrm{Cd} / \mathrm{g}$ fresh mass after 2 and 10 days 
Fig. 7 Leaf area $\left[\mathrm{cm}^{2}\right](\mathbf{a}, \mathbf{b})$, fresh mass [mg] (c, d) and dry mass [\%] $(\mathbf{e}, \mathbf{f})$ in leaves of spinach growing for 2, 4, 7 and 10 days in soil contaminated with TC (a, c, d) and $\mathrm{Cd}(\mathbf{b}, \mathbf{d}$, f) at different concentrations 0 , $3,45,90 \mathrm{mg}$ TC or $\mathrm{Cd} \mathrm{kg}^{-1}$ of soil. Means with the same letter are not significantly different from each other (Tukey test, $p \leq 0.01)$
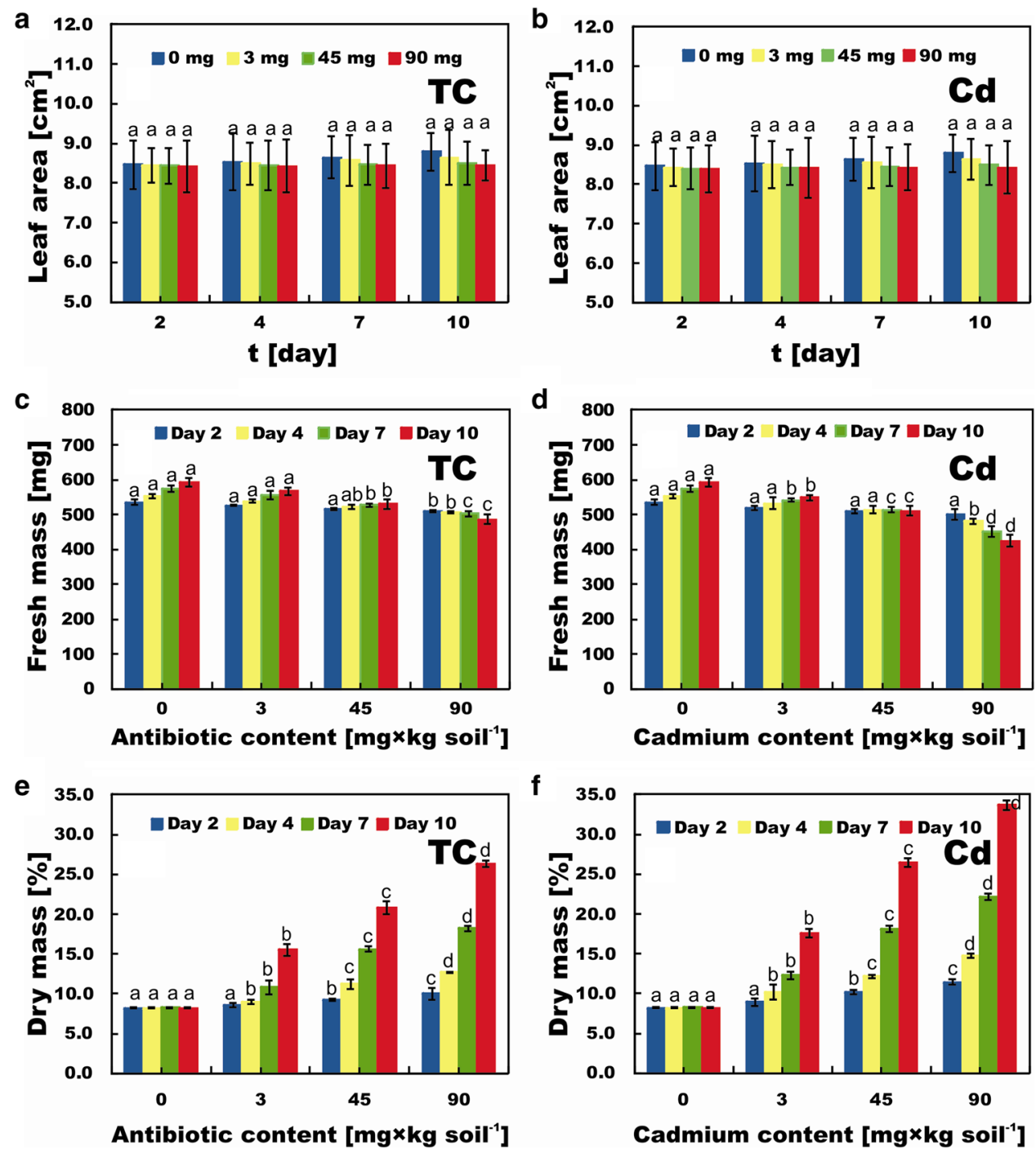

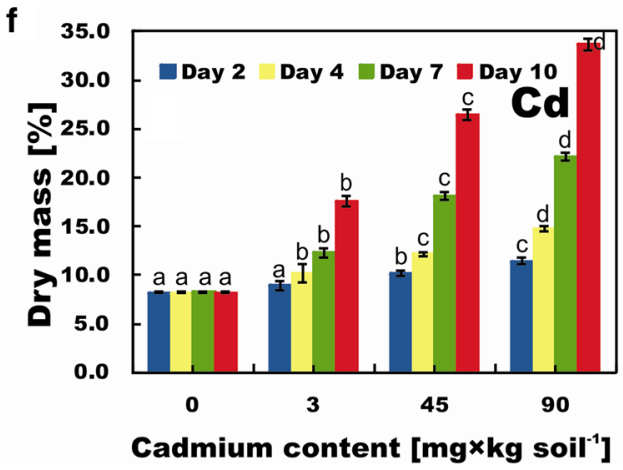

of growth, respectively. With the highest dose of Cd treatment, leaves contained 1.97 and $12.28 \mu \mathrm{g} \mathrm{Cd} / \mathrm{g}$ fresh mass after 2 and 10 days of exposure, respectively.

It must be emphasized that plants take up TC more readily than $\mathrm{Cd}$ - they contained up to 2.9 times more $\mathrm{TC}$ than $\mathrm{Cd}$ after 10 days of experiment. After a short period of pollutant treatment ( 2 days), the difference was even more notable; the level of TC was 4.5 higher compared to $\mathrm{Cd}$. We showed for the first time that plant absorbs $\mathrm{TC}$ more readily than $\mathrm{Cd}$; however, TC is less toxic. It is well documented that plants absorb both Cd (Wang et al. 2018) and TC (Margas et al. 2016); however the effects of both pollutants have not been compared so far.

\section{Predicting the chlorophyll content}

Edible plants (e.g., spinach) may become intoxicated with metals and antibiotics; it is important, therefore, to predict the changes in chlorophyll content in leaves at harvest maturity, collected from plants grown for 60 days in contaminated soil.

The uptake of tetracycline and cadmium from soil by spinach plants during 10 days results in severe changes in the plant water economy (changes in dry and fresh weights, stress reactions) and a very big drop of chlorophyll concentrations in plants, reaching 60-70\%. However, the vegetation period lasts not 10 days but almost 2 months, so an attempt was made to calculate the chlorophyll concentration in plants growing in soils contaminated with TC and Cd during this prolonged period. Due to the fact that the spinach growth period from germination to harvest is on average about 60 days, from the kinetic equation (Eq. 1) and experimentally determined $k$ and $b$ values (Table 2), it was possible to predict $\mathrm{Chl}$ content in spinach leaves after 60 days of exposure to the antibiotic and the heavy metal. The predicted concentration of chlorophyll after 60 days $\left(C_{60}\right)$ of growth in contaminated soil decreased in a TC dose-dependent fashion (Table 2): for $3 \mathrm{mg} / \mathrm{kg}$ of soil was $C_{60}=1.42 \times 10^{-5} \mathrm{M}$, 
Fig. 8 Activity of catalase [U] $(\mathbf{a}, \mathbf{b})$ and peroxidase $[\mathrm{U}](\mathbf{c}$, d), $\mathrm{TC}(\mathbf{e})$ and $\mathrm{Cd}(\mathbf{f})$ content [ $\mu \mathrm{g} \mathrm{TC}$ or $\mathrm{Cd} \mathrm{g}^{-1}$ fresh mass] in leaves of spinach growing for 2 , 4,7 and 10 days in soil contaminated with TC $(\mathbf{a}, \mathbf{c}, \mathbf{d})$ and $\mathrm{Cd}$ $(\mathbf{b}, \mathbf{d}, \mathbf{f})$ at different concentrations $0,3,45,90 \mathrm{mg}$ TC or $\mathrm{Cd}$ $\mathrm{kg}^{-1}$ of soil. Means with the same letter are not significantly different from each other (Tukey test, $p \leq 0.01$ )
Table 2 Predicted Chl content in spinach leaves 60 days after TC and Cd application (at full plant maturity). It was assumed that the TC and Cd concentration in leaves does not change appreciably

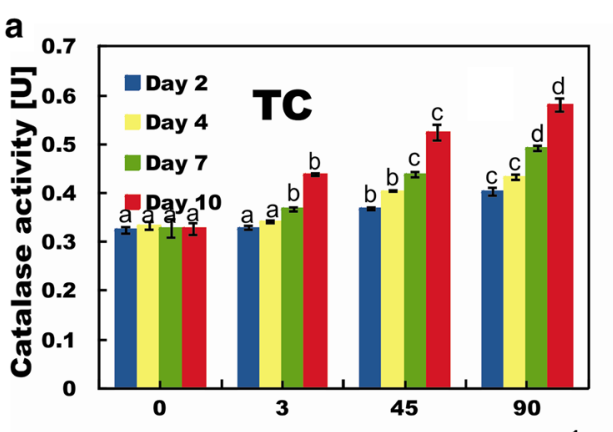

Antibiotic content [mg $\times \mathrm{kg} \mathrm{soil}^{-1}$ ]

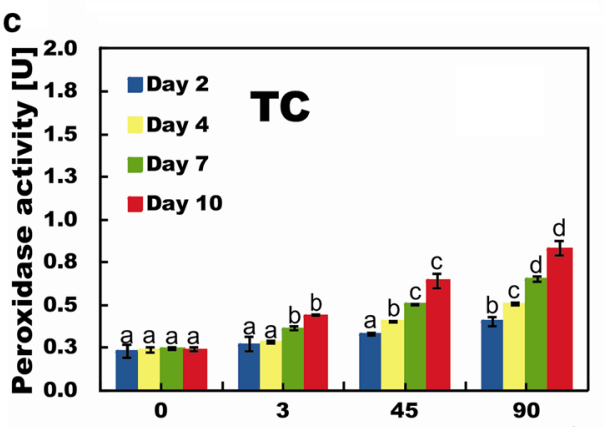

Antibiotic content [ $\mathbf{m g} \times \mathbf{k g}$ soil $^{-1}$ ]

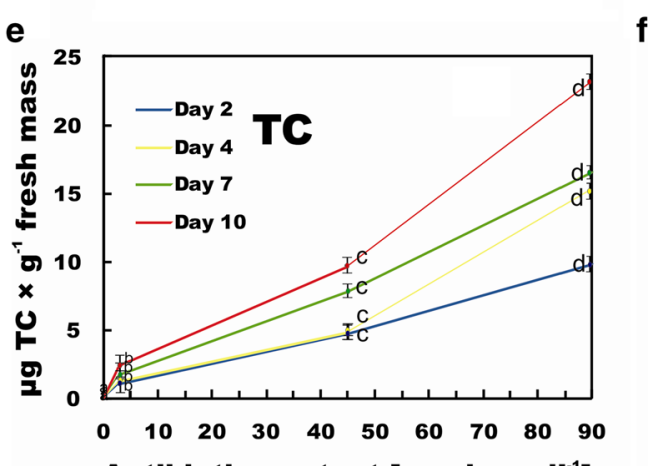

Antibiotic content [mg $\times \mathrm{kg} \mathrm{soil}^{-1}$ ]

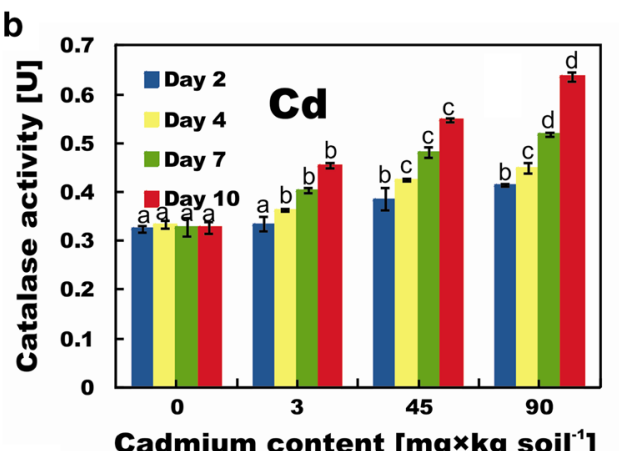

d

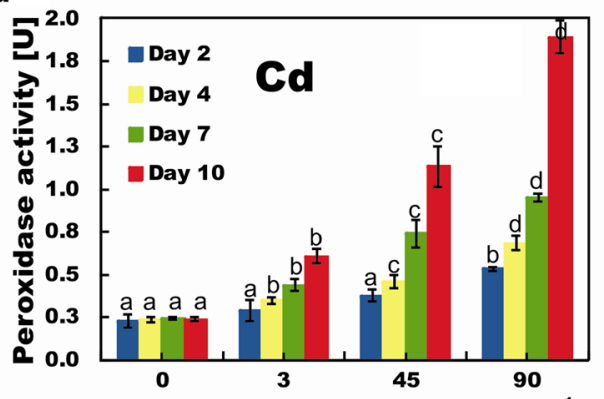

Cadmium content [mg $\times \mathrm{kg} \mathrm{soil}^{-1}$ ]

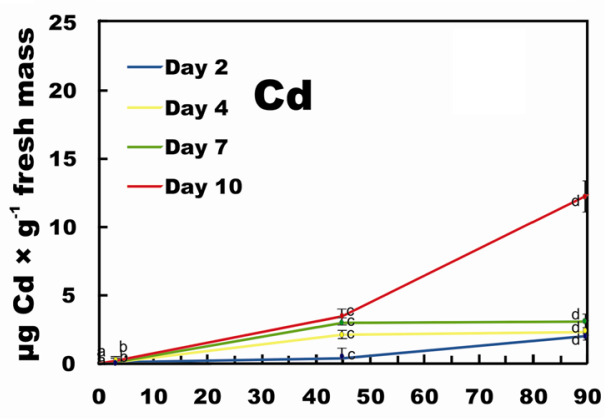

Cadmium content [mg $\times \mathbf{k g ~ s o i l}^{-1}$ ]

\begin{tabular}{|c|c|c|c|c|c|c|c|c|}
\hline \multirow{2}{*}{$\begin{array}{l}\text { Dose } \\
\left(\mathrm{mg} \times \mathrm{kg}^{-1}\right)\end{array}$} & \multicolumn{2}{|l|}{ Control } & \multicolumn{2}{|c|}{ After 10 days } & \multicolumn{2}{|c|}{ After 60 days } & \multirow[b]{2}{*}{$k$} & \multirow[b]{2}{*}{$b=1 / C_{0}$} \\
\hline & $C_{0}(\mathrm{M})$ & $\%$ & $C_{10}(\mathrm{M})$ & $\%$ & $C_{60}(\mathrm{M})$ & $\%$ & & \\
\hline \multicolumn{9}{|l|}{$\mathrm{TC}$} \\
\hline 3 & $7.88 \times 10^{-5}$ & 100 & $4.32 \times 10^{-5}$ & 55 & $1.42 \times 10^{-5}$ & 18 & 962 & 12,710 \\
\hline 45 & $7.88 \times 10^{-5}$ & 100 & $3.39 \times 10^{-5}$ & 43 & $9.26 \times 10^{-6}$ & 12 & 1598 & 12,140 \\
\hline 90 & $7.88 \times 10^{-5}$ & 100 & $2.82 \times 10^{-5}$ & 36 & $6.97 \times 10^{-6}$ & 9 & 2183 & 12,390 \\
\hline \multicolumn{9}{|l|}{$\mathrm{Cd}$} \\
\hline 3 & $7.88 \times 10^{-5}$ & 100 & $4.09 \times 10^{-5}$ & 50 & $1.25 \times 10^{-5}$ & 16 & 1126 & 12,420 \\
\hline 45 & $7.88 \times 10^{-5}$ & 100 & $3.17 \times 10^{-5}$ & 40 & $8.25 \times 10^{-6}$ & 10 & 1823 & 11,900 \\
\hline 90 & $7.88 \times 10^{-5}$ & 100 & $2.55 \times 10^{-5}$ & 32 & $6.01 \times 10^{-6}$ & 8 & 2576 & 11,930 \\
\hline
\end{tabular}

for $45 \mathrm{mg} / \mathrm{kg}$ of soil was $C_{60}=9.26 \times 10^{-6} \mathrm{M}$, for $90 \mathrm{mg}$ / $\mathrm{kg}$ of soil $C_{60}=6.97 \times 10^{-6} \mathrm{M}$, that corresponded to $18 \%$, $12 \%$ and $9 \%$, respectively, of the initial chlorophyll concentration $C_{0}=7.88 \times 10^{-5} \mathrm{M}$ (measured in plants growing in non-contaminated soil).
In the case of $\mathrm{Cd}$ application (Table 2), the predicted chlorophyll concentration drops after 60 days of spinach growth were sharper: $C_{60}=1.25 \times 10^{-5} \mathrm{M}, C_{60}=8.25 \times 10^{-6} \mathrm{M}$ and $C_{60}=6.01 \times 10^{-6} \mathrm{M}$, which corresponded to $16 \%, 10 \%$ and $8 \%$, respectively, of the initial chlorophyll concentration 
$C_{0}=7.88 \times 10^{-5} \mathrm{M}$ (found in plants growing in non-contaminated soil).

After the growth period (60 days), there should be only about 9\% Chl left in plants. This estimation is of course based on the assumption that the rate of chlorophyll degradation (and possibly replacement) in spinach does not change significantly and proceeds with the pace noted by us during the 10 days of our experiments. As can be seen in Fig. 8, however, the disturbances caused by very high levels of the drug and $\mathrm{Cd}$ are not proportional to the doses. At the acceptable Cd dose ( $3 \mathrm{mg} / \mathrm{kg}$ of soil), Chl degradation reached $50 \%$ after 10 days, but a 30 times higher dose equaling $90 \mathrm{mg} /$ $\mathrm{kg}$ resulted in a chlorophyll drop by just $64 \%$ for TC and $68 \%$ for $\mathrm{Cd}$.

Tetracycline and Cd-induced degradation of chlorophyll in spinach leaves is fairly rapid. Tetracycline degrades chlorophyll with the reaction rate constant $k=960 \mathrm{M}^{-1} \mathrm{day}^{-1}$ for $3 \mathrm{mg} \mathrm{TC} / \mathrm{kg}$ of soil. Cadmium, on the other hand, degrades chlorophyll with a reaction rate constant $k=1130 \mathrm{M}^{-1}$ day $^{-1}$ for $3 \mathrm{mg} \mathrm{Cd} / \mathrm{kg}$ of soil. Cadmium incorporated into chlorophyll has a very toxic effect on plants. We have shown that a small amount of $\mathrm{Cd}$ may degrade chlorophyll as intensely as a high dose of TC. Biochemical/enzymatic analyses have also shown that cadmium is more phytotoxic than tetracycline.

\section{Conclusion}

This paper proves that soil contamination with tetracycline and cadmium results in chlorophyll degradation in plants. Tetracycline is taken up by plants more readily than cadmium; however, the phytotoxic effect of cadmium (reflected in enzyme activity, dry mass, fresh mass, and leaf area) is much stronger compared to tetracycline. Moreover, cadmium induces a bigger drop in chlorophyll content. The appearance of new fluorescence bands, shifted relative to the bands of pure chlorophyll, suggests the formation of chlorophyll degradation products. In plants both types of chlorophyll degradation (by TC and $\mathrm{Cd}$ ) are second-order reactions (so their rates depend both on the contaminant concentration and chlorophyll concentration) and the rate constant of chlorophyll degradation by $\mathrm{Cd}$ is higher than the rate constant of chlorophyll degradation by TC. The changes in chlorophyll molecules as manifested by the drops of light absorption and fluorescence by chlorophyll contribute to the decrease in efficiency of photosynthesis in TC and Cd-intoxicated plants. The changes in energy quanta absorbed and emitted by chlorophyll indicate that the nonradiative energy transfer from light harvesting antennae to the photosynthetic reaction center is impossible and results in the breakdown of photosynthesis.

Acknowledgements The authors are grateful for financial support from the National Science Centre of Poland (N N 305 275440).

\section{Compliance with ethical standards}

Conflict of interest The authors declare that they have no conflict of interest.

Open Access This article is distributed under the terms of the Creative Commons Attribution 4.0 International License (http://creativeco mmons.org/licenses/by/4.0/), which permits unrestricted use, distribution, and reproduction in any medium, provided you give appropriate credit to the original author(s) and the source, provide a link to the Creative Commons license, and indicate if changes were made.

\section{References}

Alloway BJ, Steinnes E (1999) Anthropogenic addition of cadmium to soils. In: McLaughlin MJ, Singh BR (eds) Cadmium in soils and plants, Chapter 5. Kluwer Academic Publishers, Dordrecht, pp 97-123 (Chapter 5)

Andresen E, Küpper H (2013) Cadmium toxicity in plants. Met Ions Life Sci 11:395-413

Bechaieb R, Ben Akacha A, Gérard H (2016a) Quantum chemistry insight into $\mathrm{Mg}$-substitution in chlorophyll by toxic heavy metals: $\mathrm{Cd}, \mathrm{Hg}$ and $\mathrm{Pb}$. Chem Phys Lett 663:27-32

Bechaieb R, Fredj AB, Akacha AB, Gérard H (2016b) Interactions of copper(II) and zinc(II) with chlorophyll: insights from density functional theory studies. New J Chem 40:4543-4549

Bradford MM (1976) Rapid and sensitive method for the quantitation of microgram quantities of protein utilizing the principle of protein-dye binding. Anal Biochem 72:248-254

Chen Z, Zhu D, Wu J, Cheng Z, Yan X, Deng X, Yan Y (2018) Identification of differentially accumulated proteins involved in regulating independent and combined osmosis and cadmium stress response in Brachypodium seedling roots. Sci Rep 8(1):7790

Chernomorsky S, Segelman A, Poretz RD (1999) Effect of dietary chlorophyll derivatives on mutagenesis and tumor cell growth. Teratog Carcinog Mutagen 19:313-322

Di Marco G, Gismondi A, Canuti L, Scimeca M, Volpe A, Canini A (2014) Tetracycline accumulates in Iberis sempervirens L. through apoplastic transport inducing oxidative stress and growth inhibition. Plant Biol 16:792-800

Endo Y, Usuki R, Kaneda T (1985) Antioxidant effects of chlorophyll and pheophytin on the autoxidation of oils in the dark. II. The mechanism of antioxidative action of chlorophyll. J Am Oil Chem Soc 62:1387-1390 
Gill SS, Tuteja N (2010) Reactive oxygen species and antioxidant machinery in abiotic stress tolerance in crop plants. Plant Physiol Biochem 48:909-930

Gill SS, Khan NA, Tuteja N (2012) Cadmium at high dose perturbs growth, photosynthesis and nitrogen metabolism while at low dose it up regulates sulfur assimilation and antioxidant machinery in garden cress (Lepidium sativum L.). Plant Sci 182:112-120

Hsu CY, Yang CM, Chen CM, Chao PY, Hu SP (2005) Effects of chlorophyll-related compounds on hydrogen peroxide induced DNA damage within human lymphocytes. J Agric Food Chem 53:2746-2750

IUNG (2017) Monitoring Chemizmu Gleb Ornych Polski (In Polish). https://www.gios.gov.pl/chemizm_gleb/index.php?mod=wynik i\&cz $=\mathrm{G}$. Accessed 12 Dec 2017

Jubert C, Mata J, Bench G, Dashwood R, Pereira C, Tracewell W, Turteltaub K, Williams D, Bailey G (2009) Effects of chlorophyll and chlorophyllin on low-dose Aflatoxin $\mathrm{B}_{1}$ pharmacokinetics in human volunteers. Cancer Prev Res 2:1015-1022

Kang MS, Kim JH, Shin BA, Lee HC, Kim YS, Lim HS, Oh JS (2013) Inhibitory effect of chlorophyllin on the propionibacterium acnesinduced chemokine expression. J Microbiol 51:844-849

Kang YR, Park J, Jung SK, Chang YH (2018) Synthesis, characterization, and functional properties of chlorophylls, pheophytins, and Zn-pheophytins. Food Chem 245:943-950

Küpper H, Küpper F, Spiller M (1996) Environmental relevance of heavy metal substituted chlorophylls using the example of water plants. J Exp Bot 47:259-266

Küpper H, Küpper F, Spiller M (2006) [Heavy metal]-chlorophylls formed in vivo during heavy metal stress and degradation products formed during digestion, extraction and storage of plant material. In: Grimm B, Porra RJ, Rüdiger W, Scheer H (eds) Chlorophylls and bacteriochlorophylls. Advances in photosynthesis and respiration, vol 25. Springer, Dordrecht, pp 67-75

Lanfer-Marquez UM, Barros RMC, Sinnecker P (2005) Antioxidant activity of chlorophylls and their derivatives. Food Res Int 38:885-895

Mangos TJ, Berger RG (1997) Determination of major chlorophyll degradation products. Z Lebensm Unters Forsch A 204:345-350

Marcano LB, Carruyo IM, Montiel XM, Morales CB, de Soto PM (2009) Effect of cadmium on cellular viability in two species of microalgae (Scenedesmus sp. and Dunaliella viridis). Biol Trace Elem Res 130:86-93

Margas M, Piotrowicz-Cieślak AI, Ziółkowska A, Adomas B (2016) Tetracycline accumulation in pea seedlings and its effects on proteome and enzyme activities. Int J Agric Biol 18:789-796

Pailler JY, Krein A, Pfister L, Hoffmann L, Guignard C (2009) Solid phase extraction coupled to liquid chromatography-tandem mass spectrometry analysis of sulfonamides, tetracyclines, analgesics and hormones in surface water and wastewater in Luxembourg. Sci Total Environ 407:4736-4743

Pan M, Chu LM (2016) Phytotoxicity of veterinary antibiotics to seed germination and root elongation of crops. Ecotoxicol Environ Saf 126:228-237

Patar AK, Bhan S, Syiem D (2016) Effect of chlorophyllin, an semisynthetic chlorophyll molecule on hyperglycemia and hyperlipidemia in streptozotocin induced diabetic mice. Int J Pharm Pharm Sci 8:293-296

Roberts TL (2014) Cadmium and phosphorous fertilizers: the issues and the science. Procedia Eng 83:52-59

Rydzyński D, Piotrowicz-Cieślak AI, Grajek H, Michalczyk DJ (2017) Instability of chlorophyll in yellow lupin seedlings grown in soil contaminated with ciprofloxacin and tetracycline. Chemosphere $184: 62-73$

Sanitá di Toppi LS, Gabbrielli R (1999) Response to cadmium in higher plants. Environ Exp Bot 41:105-130
Schneider S, Schmitt MO, Brehm G, Reiher M, Matousek P, Towrie M (2003) Fluorescence kinetics of aqueous solutions of tetracycline and its complexes with $\mathrm{Mg}^{2+}$ and $\mathrm{Ca}^{2+}$. Photochem Photobiol Sci 2:1107-1117

Seely GR, Jensen RG (1965) Effect of solvent on the spectrum of chlorophyll. Spectrochim Acta 21:1835-1845

Simonich MT, Egner PA, Roebuck BD, Orner GA, Jubert C, Pereira C, Groopman JD, Kensler TW, Dashwood RH, Williams DE, Bailey GS (2007) Natural chlorophyll inhibits aflatoxin B1-induced multi-organ carcinogenesis in the rat. Carcinogenesis 28:1294-1302

Singh G, Agnihotri RK, Reshma RS, Ahmad M (2012) Effect of lead and nickel toxicity on chlorophyll and proline content of Urd (Vigna mungo L.) seedlings. Int J Plant Physiol Biochem 4:136-141

Stockwell VO, Duffy B (2012) Use of antibiotics in plant agriculture. Rev Sci Tech 31:199-210

Suparmi S, Fasitasari M, Martosupono M, Mangimbulude JC (2016) Comparisons of curative effects of chlorophyll from Sauropus androgynus (L.) Merr leaf extract and $\mathrm{Cu}$-chlorophyllin on sodium nitrate-induced oxidative stress in rats. J Toxicol Article ID 8515089,7 pages

Tachino N, Guo D, Dashwood WM, Yamane S, Larsen R, Dashwood R (1994) Mechanisms of the in vitro antimutagenic action of chlorophyllin against benzo[a]pyrene: studies of enzyme inhibition, molecular complex formation and degradation of the ultimate carcinogen. Mutat Res Fundam Mol Mech Mutagen 308:191-203

US EPA Ecological Effects Test Guidelines (2012) OCSPP 850.4400: Aquatic Plant Toxicity Test Using Lemna spp. U.S. EPA 712-C-008

Wagner GJ (1993) Accumulation of cadmium in crop plants and its consequences to human health. Adv Agron 51:173-213

Wang J, Zhang H, Zhang T, Zhang R, Liu R, Chen Y (2015) Molecular mechanism on cadmium-induced activity changes of catalase and superoxide dismutase. Int J Biol Macromol 77:59-67

Wang K, Wang F, Song N, Liu J, Zhang T, Wang M, Wang Y (2018) Contribution of root uptake to cadmium accumulation in two peanut cultivars: evidence from a split-column soil experiment. Ecotoxicol Environ Saf 25:15036-15043

Wardman P, Candeias LP (1996) Fenton chemistry: an introduction. Radiat Res 145:523-531

Weagle G, Gupta A, Bérubé G, Chapados C (2010) Evaluation of in vivo biological activities of tetrapyrrole ethanolamides as novel anticancer agents. J Photochem Photobiol B 100:44-50

Xie X, Zhou Q, Lin D, Guo J, Bao Y (2011) Toxic effect of tetracycline exposure on growth, antioxidative and genetic indices of wheat (Triticum aestivum L.). Environ Sci Pollut Res 18:566-575

Yang LP, Zhu J, Wang P, Zeng J, Tan R, Yang YZ, Liu ZM (2018) Effect of $\mathrm{Cd}$ on growth, physiological response, $\mathrm{Cd}$ subcellular distribution and chemical forms of Koelreuteria paniculata. Ecotoxicol Environ Saf 160:10-18

You H, Yoon HE, Yoon JH, Ko H, Kim YC (2011) Synthesis of pheophorbide-a conjugates with anticancer drugs as potential cancer diagnostic and therapeutic agents. Bioorg Med Chem 19:5383-5391

Yousefi Z, Kolahi M, Majd A, Jonoubi P (2018) Effect of cadmium on morphometric traits, antioxidant enzyme activity and phytochelatin synthase gene expression (SoPCS) of Saccharum officinarum var. cp48-103 in vitro. Ecotoxicol Environ Saf 157:472-481

Zhang H, Ding Y, Zhi J, Li X, Liu H, Xu J (2018a) Over-expression of the poplar expansin gene PtoEXPA12 in tobacco plants enhanced cadmium accumulation. Int J Biol Macromol 116:676-682

Zhang XD, Sun JY, You YY, Song JB, Yang ZM (2018b) Identification of Cd-responsive RNA helicase genes and expression of a putative BnRH 24 mediated by miR158 in canola (Brassica napus). Ecotoxicol Environ Saf 157:159-168 
Zhao FJ, Hamon RE, Lombi E, McLaughlin MJ, McGrath SP (2002) Characteristics of cadmium uptake in two contrasting ecotypes of the hyperaccumulator Thlaspi caerulescens. J Exp Bot 53:535-543

Zvezdanović JB, Petrović SM, Marković DZ, Andjelković TD, Andjelković DH (2014) Electrospray ionization mass spectrometry combined with ultra high performance liquid chromatography in the analysis of in vitro formation of chlorophyll complexes with copper and zinc. J Serb Chem Soc 79:689-706 